\title{
Bactericidal efficiency of preparation based on essential oils used in aerosol disinfection in the presence of poultry
}

\author{
G. V. Ponomarenko*, V. L. Kovalenko**, Y. O. Balatskiy***, \\ O. V. Ponomarenko*, A. P. Paliy****, S. V. Shulyak***** \\ *Kharkiv State Zooveterinary Academy, Kharkiv, Ukraine \\ **State Scientific Control Institute of Biotechnology and Strains of Microorganisms, Kyiv, Ukraine \\ ***Bila Tserkva National Agrarian University, Bila Tserkva, Ukraine \\ ****National Scientific Center "Institute of Experimental and Clinical Veterinary Medicine", Kharkiv, Ukraine \\ *****State Scientific and Research Institute of Laboratory Diagnostics and Veterinary and Sanitary Expertise, Kyiv, Ukraine
}

Article info

Received 25.09.2021

Received in revised form 18.10.2021

Accepted 20.10.2021

Kharkiv State Zooveterinary Academy Academic st, 1, Malaya Danilovka, Dergachi district, Kharkov region, 62341,

Ukraine. Tel.: +380-50-589-73-15.

E-mail:gpkh1966@gmail.com

State Scientific Control Institute of Biotechnology and Strains Microorganisms, Donetska st, 30, Kyiv, 03151, Ukraine Tel : +38-067-756-86-44. E-mail:kovalenkodoktor@gmail.com

Bila Tserkva National Agrarian University, Soborna sq, 8/1, Bila Tserkva, 09117, Ukraine. Tel.: +38-098-526-48-73.

E-mail:balatskiyy@ukr.net

Institute of Experimental and Clinical Veterinary Medicine, Pushkinska st., 83, Kharkiv, 61023, Ukraine.

Tel.: +38-066-225-34-34

E-mail:paliy.dok@gmail.com

State Scientific and Research Institute of Laboratory Diagnostics and Veterinary and Sanitary Expertise, Donetska st., 30, Kyiv, 03151, Ukraine.

Tel.: +38-067-756-86-44.

E-mail:kovalenkodoktor@gmail.com
Ponomarenko, G. V., Kovalenko, V. L., Balatskiy, Y. O., Ponomarenko, O. V., Paliy, A. P., \& Shulyak, S. V. (2021). Bactericidal efficiency of preparation based on essential oils used in aerosol disinfection in the presence of poultry. Regulatory Mechanisms in Biosystems, 12(4), 635-641. doi:10.15421/022187

A disinfectant was created for aerosol disinfection of premises in the presence of poultry, which will help reduce microbial contamination of premises, increase survival, weight of poultry and economic efficiency of meat production in general. The preparation based on essential oils can be used for disinfection in the presence of poultry and at the same time exhibits a therapeutic and prophylactic effect on respiratory infections. This disinfectant has a colloidal solution of silver (Ag), benzalkonium chloride and essential oils of thyme, fir and eucalyptus. The preparation based on essential oils contains (per $100 \mathrm{~g}$ ): benzalkonium chloride - $16.0 \mathrm{~g}$; thyme oil - up to $2.0 \mathrm{~g}$; eucalyptus oil - up to $2.0 \mathrm{~g}$; fir oil - up to $2.0 \mathrm{~g}$; colloidal solution of silver (Ag) - 20-30 mg; distilled water - up to $100 \mathrm{~cm}^{3}$. Aerosol sanitation of indoor air was carried out with $0.3 \%$ solution of preparation in the period before housing poultry and once a day from the 20 th to the 35 th day of growing broilers with aerosol cold mist generator Dyna-Fog Tornado (model 2897, construction type - ULV-electric spray gnerator, manufacturer - Curtis Dyna-Fog, Ltd., USA) at a dose of $50.0 \mathrm{~cm}^{3}$ per $1 \mathrm{~m}^{3}$ at an exposure of 60 minutes. The size of the aerosol particles is $20 \mu \mathrm{m}$. On days $1,4,8,11,15,28,37$, and 42 , the chickens were weighed, and the blood was taken for examination. Blood was examined to study the number of red blood cells, hemoglobin content, the bactericidal activity of blood serum, phagocyte activity of leukocytes, lysozyme activity of blood serum. According to the results of the research, the technological modes of air disinfection of poultry premises in the presence of broiler chickens were substantiated during the use of preparation, which contains nanoparticles (NP) of silver, benzalkonium chloride and essential oils. The optimal mode of aerosol treatment of poultry houses using a $0.3 \%$ solution preparation based on essential oils is $50 \mathrm{~mL} / \mathrm{m}^{3}$ of a room with a 60 -minute exposure. The use of air disinfection in the presence of chickens during broiler rearing and one treatment per day from 20 to 35 days of the chickens' growth reduced the microbial pollution of indoor air. Thus, the concentration of microbial cells in the room where the chickens were kept was $230.2 \pm 15.6$ thousand microbial cell $/ \mathrm{m}^{3}$. Sixty minutes after disinfection, the concentration decreased to $1.4 \pm 0.4$ thousand microbial cell $/ \mathrm{m}^{3}$. In addition, the bodyweight of chickens at 6 weeks increased by $449.4 \pm$ $16.3 \mathrm{~g}(15.9 \%)$ compared with the controls. The method and mode of air treatment did not adversely affect the development of the internal organs of the poultry and their physiological state, which is confirmed by studies of the morphological parameters of the chicken blood. The data obtained indicate a positive effect of the developed methods and modes of aerosol air treatment with the preparation based on essential oils on the growth and development of broilers.

Keywords: essential oils; aerosol disinfection; broiler chickens; indoor air

\section{Introduction}

The growth of the world's population requires the production of quality food. Poultry meat (broiler) is extremely nutritious, has high cooking characteristics and dietary properties. Broiler production is developing rapidly enough today. Due to the problem of African swine fever in Ukraine, Europe and Asia (Ben Sassi et al., 2016; Biesek et al., 2020), the number of pigs and the share of pork in the consumer market are rapidly decreasing. Indeed, among 440 million pigs in China (almost half the number of pigs in the world), at the end of 2019, less than half remained. Poultry meat, including broiler chicken meat, will more actively substitute pork in the consumer market. However, broiler chickens are affected by a large number of infectious pathogens that circulate in poultry facilities and in poultry (Alvarez et al., 2019; Borges et al., 2019; Rawson et al., 2019) Therefore, conducting high-quality disinfection of poultry facilities (including in the presence of poultry) is an important task. The reliable disinfection of production facilities for keeping poultry is a condition of effective industrial poultry farming. The most significant parameter of disinfection efficiency is the reduction of microbial contamination of the air in poultry farms (Diadychkyna, 2011; Buckmaster, 2012; Addie et al., 2015). Disinfectants used in premises have a different focus and mechanism of action on microbial cells (Jiang et al., 2018; Maertens et al., 2018; Paliy et al., 2018; Zazharskyi et al., 2020). Currently, preparations of ammonium compounds and colloidal silver are widely used for disinfection (Park et al., 2009; Ding et al., 2019; Diaz et al., 2019). Although the antibacterial properties of silver have been known for many centuries, the 
exact mechanism of this action remains the subject of discussion. Silver nanoparticles, AgNP, have the ability to attach to the cell wall of bacteria and eventually penetrate into it, thereby causing structural changes in the cell membrane (Sondi \& Salopek-Sondi, 2004; Morones et al., 2005; Kim et al., 2007). Sondi \& Salopek-Sondi (2004) indicated that silver-treated Escherichia coli cells were significantly damaged, and the cell membrane of such bacteria was deeply pitted. Moreover, AgNP penetrated into the cell walls, accumulated in the membrane and partially penetrated into the cell itself. Fewtrell et al. (2014) indicates that AgNP can cause the generation of free radicals (such as with ionic silver), and subsequently leads to further damage to bacterial cells. It was also suggested that nanoparticles could secrete silver ions (Liau et al., 1997; Feng et al., 2000), and these ions can interact with thiol groups of many vital enzymes (Matsumura et al., 2003).

Inhibition of bacterial functions is associated with the formation of complexes with sulfhydryl groups and inactivation of enzymes on the surface of the bacterial cell, resulting in altered respiratory processes in the cell membrane. In addition, DNA-bound silver ions block transcription, and ions bound to cell surface components stop bacterial respiration and adenine triphosphate synthesis. Interaction with external peptidoglycans of bacteria leads to blocking of their ability to transfer oxygen inside the cell of the bacteria leading to the death of the microorganism. There is a generation of reactive oxygen modifications, which are formed possibly due to the suppression of the respiratory enzyme by silver ions, and attack the cell itself. According to the classification of Hard and Soft Acids and Bases, silver, as a soft acid, has a natural tendency to react with a soft base (Morones et al., 2005). Cells are predominantly composed of sulfur and phosphorus, which are also soft bases. The effect of these nanoparticles on the cell can cause a reaction and subsequently lead to cell death. DNA contains the main component of sulfur and phosphorus; nanoparticles act on these soft bases and destroy DNA, which certainly leads to cell death. Active interaction of particles with bacterial cells leads to a rapid loss of bactericidal potential (Hatchett \& White, 1996). To increase the duration of exposure to silver $(\mathrm{Ag})$ nanoparticles, they are used in combination with essential oils of fir tree and eucalyptus (Kovalenko et al., 2018). Such essential oils, in addition to stabilizing the aerosol, are active against various bacteria themselves. So, essential oils of cinnamon, thyme, garden savory, common balm, lavender, mint, rosemary, marjoram, thyme, cloves, geranium, lemon, lime, orange are active against Streptococcus, Actinobacillus, Bordetella, Haemophilus, Pasteurella, Salmonchoma, Schmonizoma, Schmonizoma, Escherichia, Staphylococcus, Listeria even in small concentrations (Das et al., 2019; Lagha et al., 2019; Olaimat et al., 2019), oils from spruce needles have a bactericidal effect on Pseudomonas, Enterococcus, Candida, Staphylococcus, Bacillus cereus, Salmonella (Fyhrquist et al., 2017) and also destroy the biofilms of bacteria (Wojnicz et al., 2012; Kim \& Park, 2013). Essential oils affect the multidrugresistant forms of these pathogens. The mechanisms of action of bactericidal doses of essential oils are the destruction of the membrane structures of microbial cells with subsequent disruption of intracellular metabolism and bacteria death (Soliman et al., 2017; Taiwo \& Adebayo, 2017; Vasireddy et al., 2018). Thus, essential oils, exhibiting bactericidal properties against bacteria in the body of animals already sick with respiratory diseases can be useful components of antibacterial preparations enhancing their effect (Man et al., 2019).

All quaternary ammonium compounds (QAC), in particular benzalkonium chloride, are effective and low toxic disinfectants. The abovementioned compounds penetrate the walls of bacteria, interact with the cytoplasmic membrane, and autolytic enzymes lead to the lysis of wall structures (McDonnell \& Russell, 1999). QACs do not have high corrosivity at low working concentrations and retain their activity well. Such disinfectants affect a wide range of microorganisms; they do not have significant toxicity at recommended concentrations, and are stable during storage. The preparations affect Escherichia coli and Staphylococcus aureus in low concentrations and with short contact (Suchomel et al., 2019), they are effective against bacteria that form biofilms (Baranowska et al., 2014). Benzalkonium chloride is quite active against multidrug-resistant gram-negative bacteria (MDR-GNB) (Köhler et al., 2019). Moreover, despite their relatively mild effect, researchers recommend the use of preparations of this group for the disinfection of fruits and vegetables (Chaidez et al., 2007).
With a significant number of poultry in limited areas, birds are capable of excreting viruses and bacteria thorugh secretions and excrement creating an aerosol of pathogens in the air of the poultry house, which can be harmful to other poultry, people, and the environment (Petkov et al., 1987; Just et al., 2011). This implies that it is necessary to influence such bacterial and viral aerosols using aerosol disinfection methods and preparations intended for this purpose. Indeed, such preparations have insignificant corrosion activity and at the same time are quite active against these biological aerosols (Carvalho et al., 2015; Saklou et al., 2016).

The resistance of pathogenic microorganisms and their ability to adapt to disinfecting preparations is an urgent issue. Therefore, it is necessary to carry out the rotation and timely change of disinfectants, taking into account their various active substances. When determining the rotation pattern of disinfectants, it is necessary to take into account their effectiveness against specific pathogens, as well as methods of application in various industrial situations (Kim et al., 2016; Richards et al., 2016; Ponomarenko et al., 2017). In addition to high efficiency, the aerosol method, in comparison with wet methods of disinfection reduces the cost of disinfectants and human labour several times. Aerosol disinfection can be carried out in the presence of animals and poultry, but this method of sanitation has high requirements for the safety of the agent's effect on the body of both humans and animals (Diadychkyna, 2011; Souza et al., 2015; Lopes et al., 2016).

In previous studies, we successfully used the Geocid preparation based on QACs, which we developed for aerosol disinfection of pig and livestock breeding farms, and which showed good sanitary and hygienic characteristics and turned out to be an extremely effective tool to combat Staphylococcus spp., Streptococcus spp., Salmonella spp., Klebsiella pneumonica, Escherichia coli, Pseudomonas aeruginos, Mycobacterium fortuitum, Campylobacter jejuni, Proteus vulgaris and other bacteria, showed sporicidal (microorganisms of the genus Bacillus), fungicidal (Aspergillus flavaus, Candidida albicans), virucidal, insecticidal and acaricidal properties. The Geocid disinfectant has been successfully used for disinfection of premises in the presence of animals (Kovalenko et al., 2018). Subsequently, we obtained the Sriblobenz disinfectant, which consists of a colloidal solution with silver nanoparticles and benzalkonium chloride. In this preparation, silver nanoparticles are coated with a layer of benzalkonium chloride surfactant. The application of this colloidal mixture makes it possible to prolong the effect of the Sriblobenz preparation as a result of the sequential effect of the components: first benzalkonium chloride, then silver nanoparticles.

In this study, we developed a new, environmentally friendly, highly effective antibacterial preparation based on essential oils using a benzalkonium chloride, thyme, eucalyptus, fir tree oil and silver (Ag) colloidal solution. All these components allow one, in a short time, to effectively carry out a comprehensive sanitization of livestock facilities in the presence of animals. In production conditions, disinfectant solutions in addition to microorganisms come into contact with various organic and inorganic compounds causing disinfectants to partially lose their activity. Therefore, there is a need to investigate the preparation during exposure to environmental factors, using proteins (protein load) in the form of inactivated serum. Working solutions are effective at high protein load (when processing objects heavily contaminated with organic matter) (Kovalenko et al., 2018).

To develop a preparation with properties of disinfectant and detergent, it is recommended to mix quaternary ammonium compounds with nonionic surfactants. Before disinfection, it is necessary to remove fats, feeds, etc., as in their presence, these substances lose their effectiveness (Rodionova et al., 2021). The presence of nonionic surfactants in the detergent improves the disinfectant properties of such preparations.

The ability to break down protein and the cleansing effect allow the use of preparation for disinfection combined with cleaning. Thus, the disinfection procedure is simplified and the need for additional costs for the purchase of a separate preparation for cleaning and disinfection is eliminated. The preparation based on essential oils in $0.3 \%$ concentration was successfully tested in a pig growing industrial complex using the aerosol method. The disinfectant was used for three consecutive days at an exposure of 30 minutes daily. Two hundred animals underwent disinfection. Both during and after treatment, no harmful effects of the preparation 
on the organism of experimental animals were observed. However, compared with the control (200 animals), in experimental animals 9-10 days after the last treatment, a sharp decrease in the number of animals with bronchial pneumonia was observed (decrease to $1 \%$ among the experimental animals and 35\% in control, that is, in non-treated animals), and the total number of bacteria in the air of the room where the experimental animals were kept, after a 3-time aerosol treatment, decreased from 231 to 16 thousand $/ \mathrm{m}^{3}$ (Kovalenko et al., 2018) (the norm for growing piglets is 50 thousand $/ \mathrm{m}^{3}$ ). In addition, a three-time aerosol treatment using preparation based on essential oils $0.3 \%$ spray material for 30 min during three consecutive days at the growing site of a 200 animal pig farm ensured the safety of $98 \%$ of piglets over a 30-day period with the use of $2.0 \mathrm{~kg}$ of feed for $1 \mathrm{~kg}$ of weight gain. At the same time, in the control groups of animals, the preservation of piglets was $91 \%$ using $2.8 \mathrm{~kg}$ of feed for receiving $1 \mathrm{~kg}$ of weight gain. After obtaining such positive results in pig breeding, it was decided to use the preparation in poultry farming. The preparation based on essential oils was used in the form of $0.3 \%$ aerosol for air sanitation of a poultry farm in the presence of poultry.

\section{Materials and methods}

The experiments on animals were performed in compliance with modern bioethical requirements (Guide for the Care and Use of Laboratory Animals. 8th edition, 2011). All interventions and slaughtering of poultry were carried out in compliance with the requirements and with the permission of the Bioethics Commission of the State Scientific and Control Institute of Biotechnology and Microorganisms (Kyiv).

The studies were carried out during 42 days and were aimed at investigating the effect of various modes of disinfection with disinfectant using the aerosol method (Patent Ukraine 125935) in the presence of poultry. A disinfectant was created for aerosol disinfection of premises in the presence of animals. The basis of the procedure is a synergistic combination of disinfectants with preparations having a sanitizing and therapeutic effect. The preparation can be used for disinfection in the presence of animals and at the same time exhibits a therapeutic and prophylactic effect for respiratory infections. This disinfectant has a colloidal solution of silver (Ag), benzalkonium chloride and essential oils of thyme, fir and eucalyptus. The preparation is based on essential oils contains (per $100 \mathrm{~g}$ ): benzalkonium chloride - $16.0 \mathrm{~g}$; thyme oil - up to $2.0 \mathrm{~g}$; eucalyptus oil - up to $2.0 \mathrm{~g}$; fir oil - up to $2.0 \mathrm{~g}$; colloidal solution of silver $(\mathrm{Ag})-20-30 \mathrm{mg}$; distilled water - up to $100 \mathrm{~cm}^{3}$. Benzalkonium chloride produced by Wuhan Glory Co., Ltd, colloidal silver solution of Jiangsu XFNANO Materials Tech Co., Ltd, pharmaceutical oils of Ukrainian production were used.

The positive characteristics of the preparation include its versatility. It can be used for washing, wetting, dipping, rubbing and spraying. It is used for preventive and forced disinfection in animal husbandry, beekeeping, and poultry farming. It is used when disinfecting equipment for slaughtering animals, processing meat, dairy and processing other products of animal origin, trading, laboratory premises and devices, means for transporting animals and animal products, premises for keeping animals, sanitation in the presence of animals and partially for their treatment. The specified preparation exhibits high bactericidal, virucidal and fungicidal properties. Vegetative forms of bacteria are inactivated when the concentration of the disinfectant is $0.3-1.0 \%$ in the solution for $30 \mathrm{minu}$ tes, viruses $-0.5-1.5 \%$ - for 15 minutes.

The positive characteristics of the disinfectant should be its versatility and simplicity of production. Indeed, distilled water (instead of deionized) is successfully used as a solvent since it that makes the preparation more accessible and cheaper. The spray material of this preparation is prepared by mixing it with tap water. An important detail is the preparation of the solution on the day of the aerosol treatment. To obtain spray material, 50 $60 \mathrm{~cm}^{3}$ of the preparation are dissolved in $10 \mathrm{~L}$ of tap water. The chemical mechanism of the preparation allows preparation of the spray material in enameled, glass or plastic dishes. In this case, the water should be at room temperature. The preparation has low toxicity and high bactericidal properties due to the combination of the effect of the essential oils of thyme, fir and eucalyptus with silver (Ag) nanoparticles and benzalkonium chloride. Aerosol sanitation of indoor air was carried out with $0.3 \%$ solution of preparation in the period before housing poultry and once a day from the 20th to the 35th day of the broilers' growth using aerosol cold mist generator Dyna-Fog Tornado (model 2897, construction type - ULV-electric spray gnerator, manufacturer - Curtis Dyna-Fog, Ltd., USA) at a dose of $50.0 \mathrm{~cm}^{3}$ per $1 \mathrm{~m}^{3}$ at an exposure of 60 minutes. The size of the aerosol particles is $20 \mu \mathrm{m}$.

The research on broiler chickens was carried out in separate vivarium premises on the basis of the agricultural company Radiks LLC (Kyiv oblast). Groups of broiler chickens were formed by the method of groups of analogues. Two groups were formed from the selected chickens (control and experimental), 50 birds each. During the studies, the state and behaviour of chickens, as well as the main zoocultural and hygienic indicators of their maintenance, were monitored. Cross broiler chickens COBB-500 were kept in vivarium premises. The birds were placed in such a way that there was a maximum of 14 birds per $1 \mathrm{~m}^{2}$. The premises were kept clean. The walls and floors were well washed and disinfected before placing the chickens. Feeders, drinking bowls, lighting devices, thermometers were also disinfected before placing. Poultry house litter of sawdust was used on the floor. The feed ration was standard for the broiler depending on age. Microbial air pollution in the poultry houses was studied throughout the research. Aerosol disinfection of premises was carried out in the form of aerosol with a particle size of 5 to $25 \mu \mathrm{m}$. The quality control of disinfection was carried out by sedimentation method. Plating was carried out on open Petri dishes with meat peptone agar (to determine the number of bacteria) and separately with Saburo agar (to determine the number of micromycetes). Plating incubation was carried out in a thermostat at $37^{\circ} \mathrm{C}$ for 24 hours, and after those colonies of microorganisms were counted. Plating on Saburo agar was incubated at a temperature of $27^{\circ} \mathrm{C}$ for 5 days (Vandepitte et al., 2003; Kovalenko et al., 2011).

On days $1,4,8,11,15,28,37$, and 42 , the chickens were weighed, and the blood was taken for examination. Blood was examined to study the number of red blood cells, hemoglobin content, the bactericidal activity of blood serum, phagocyte activity of leukocytes, lysozyme activity of blood serum. Hematological, biochemical and immunological parameters of the blood were studied by conventional methods. The hemoglobin content in the blood was determined by the hemoglobin cyanide method, the number of red blood cells and white blood cells - by the tube test, in a hemocytometer, hemoglobin - using a FEK-M device. To determine the bactericidal activity of blood serum, a daily broth culture of $E$. coli, serovar O 26, grown on Hottinger broth according to the method of A. V. Smirnova, T. A. Kuzmina was used. Determination of lysozyme activity of blood serum was performed by photonephelometric method according to V. H. Dorofeichuk. Micrococcus lysodeikticus strain 2665 was taken for research. The phagocytic activity of blood leukocytes was investigated in blood stabilized with heparin using a daily broth culture of $E$. coli (strain VKM) according to the Gostev method (Vandepitte et al., 2003).

During the growing period of the chickens, we paid attention to body weight, death, development of internal organs, hematological parameters according to standard methods, as well as feed consumption (Kotsiumbas et al., 2006; Ibragimov, 2007).

Statistical analysis of the obtained experimental data was performed using ANOVA with the Tukey test $(\mathrm{P}<0.05)$ with Bonferroni correction.

\section{Results}

During 4 weeks of rearing, the survival of broilers in both groups was the same and amounted to $98 \%$. The bodyweight of chickens up to 3 weeks of age also did not differ significantly between the groups. However, on the 20th day after the start of the air treatment, the broilers of the experimental group began to grow better and were ahead of the control group in terms of the body weight. The average bodyweight of the broilers of the experimental group (Fig. 1) at 6 weeks of age was $449.4 \pm 16.3 \mathrm{~g}$ ( $\mathrm{P}<0.01$ compared with the control group) more than in the control group, which confirms the safety of the preparation based on essential oils for chicken homeostasis.

The studies showed that the broiler body weight on the 28th day in the experimental group was $965.4 \pm 20.1 \mathrm{~g}$ against $945.0 \pm 6.0 \mathrm{~g}$ in the control group; on the 37th day $-2236.0 \pm 24.9$ against $1804.0 \pm 15.6 \mathrm{~g}$, respectively; on the 42nd day of raising $-2840.0 \pm 11.5 \mathrm{~g}$ in the experi- 
mental group against 2,390.6 $\pm 27.8 \mathrm{~g}$ in the control group. It should also be noted that feed consumption per $1 \mathrm{~kg}$ of broiler body weight gain also decreased. To obtain $1 \mathrm{~kg}$ of weight gain in the control group, 2,134 \pm $88 \mathrm{~g}$ of feed was used, and in the experimental one $-1,789 \pm 27 \mathrm{~g}$. The difference was $345 \mathrm{~g}$ or $16.2 \%$. The slaughter yield of pure meat in the experimental group was $2,158.4 \pm 74.2 \mathrm{~g}$, in the control group $1,864.6 \pm 52.2 \mathrm{~g}$ and the difference was $293.8 \pm 19.4 \mathrm{~g}$ in this case. The pure meat output in percentage did not differ significantly and amounted, in the control group $-78.2 \pm 5.4 \%$ and in the experimental group $-76.1 \pm 4.7 \%$.

The data in Table 1 show a significant increase in the weight of the heart, liver, bursa, thymus of poultry after treatment of the premises with preparation in their presence. Especially important is the fact of a significant increase in the weight of lymphoid organs - bursa and thymus, because these organs affect the formation of the immune system of poultry and its ability to resist the effects of microorganisms.

Blood samples were taken to assess the state of the natural resistance in broilers of the control and experimental groups on 1, 4, 8, 11, 15, 28, 37 and 42 days of raising. Blood test results revealed a slight increase in the number of red blood cells and a decrease in the level of leukocytes in broilers of the experimental group, which indicated a decrease in the effect of conditionally pathogenic microflora on the bird organism constantly present in the poultry house (Table 2).

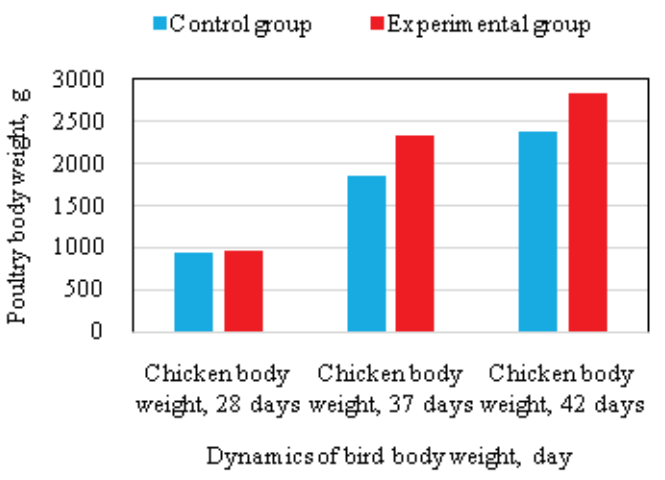

Fig. 1. Indicators of broiler raising using the preparation based on essential oils, $0.3 \%$, after disinfection of indoor air

Normal indicators in chickens: red blood cells $-3-4$ thousand L; leukocytes - 20-40 g/L; hemoglobin - 80-120 g/L; phagocytic activity $40-60 \%$; lysozyme activity $-30-55$; bactericidal activity $-40-60 \%$.

Table 1

Dynamics of weight of the internal organs when using preparation based on essential oils $(x \pm S D, n=100)$

\begin{tabular}{|c|c|c|c|c|c|c|}
\hline \multirow{2}{*}{ Indicators } & \multicolumn{2}{|c|}{28 days } & \multicolumn{2}{|c|}{37 days } & \multicolumn{2}{|c|}{42 days } \\
\hline & control group & experiment group & control group & experiment group & control group & experiment group \\
\hline Heart & $4.93 \pm 0.28^{\mathrm{a}}$ & $5.37 \pm 0.33^{\mathrm{a}}$ & $7.98 \pm 0.37^{b}$ & $8.50 \pm 0.77^{\mathrm{b}}$ & $10.21 \pm 0.48^{\mathrm{c}}$ & $10.80 \pm 1.01^{\mathrm{c}}$ \\
\hline Liver & $24.65 \pm 1.66^{\mathrm{a}}$ & $28.53 \pm 2.02^{\mathrm{a}}$ & $35.63 \pm 2.11^{b}$ & $48.51 \pm 1.60^{\mathrm{bc}}$ & $44.50 \pm 1.65^{\mathrm{bc}}$ & $61.69 \pm 1.89^{c}$ \\
\hline Spleen & $1.00 \pm 0.12^{\mathrm{a}}$ & $1.14 \pm 0.05^{\mathrm{a}}$ & $2.14 \pm 0.25^{b}$ & $2.49 \pm 0.39^{\mathrm{bc}}$ & $2.70 \pm 0.31^{b c}$ & $3.00 \pm 0.19^{c}$ \\
\hline Bursa of Fabricius & $1.37 \pm 0.22^{\mathrm{a}}$ & $1.53 \pm 0.32^{\mathrm{a}}$ & $1.77 \pm 0.30^{\mathrm{ab}}$ & $1.98 \pm 0.27^{\mathrm{ab}}$ & $2.33 \pm 0.23^{b}$ & $2.83 \pm 0.26^{b}$ \\
\hline $\begin{array}{l}\text { Thymus } \\
\text { The }\end{array}$ & $4.19 \pm 0.66^{\mathrm{a}}$ & $4.33 \pm 0.70^{\mathrm{a}}$ & $7.77 \pm 0.69^{b}$ & $10.61 \pm 0.43^{\mathrm{bc}}$ & $9.45 \pm 0.39^{\mathrm{bc}}$ & $13.50 \pm 0.36^{\mathrm{c}}$ \\
\hline
\end{tabular}

Note: differences between the indicators were taken into account according to the results of the Tukey test $(\mathrm{P}<0.05)$ with Bonferroni correction.

Table 2

Age-related dynamics of hemoglobin, lysozyme blood activity, leukocyte and red blood cell counts in the blood of broiler chickens of both control and experimental groups $(x \pm S D, n=100)$

\begin{tabular}{|c|c|c|c|c|c|c|c|c|c|}
\hline \multirow{2}{*}{\multicolumn{2}{|c|}{ Indicator, units of measurement }} & \multicolumn{8}{|c|}{ Age of chickens, days } \\
\hline & & 1 & 4 & 8 & 11 & 15 & 28 & 37 & 42 \\
\hline \multirow{2}{*}{ Hemoglobin, g/L } & A & $91.90 \pm 0.82^{\mathrm{a}}$ & $91.49 \pm 0.80^{\mathrm{a}}$ & $92.31 \pm 0.39^{\mathrm{a}}$ & $89.15 \pm 1.02^{\mathrm{a}}$ & $89.15 \pm 1.06^{\mathrm{a}}$ & $89.80 \pm 1.49^{\mathrm{a}}$ & $90.12 \pm 1.84^{\mathrm{a}}$ & $90.96 \pm 1.60^{\mathrm{a}}$ \\
\hline & B & $88.00 \pm 1.26^{\mathrm{a}}$ & $90.71 \pm 0.58^{\mathrm{a}}$ & $92.54 \pm 0.25^{\mathrm{a}}$ & $95.22 \pm 1.43^{\mathrm{a}}$ & $101.71 \pm 1.39^{\mathrm{b}}$ & $105.11 \pm 2.10^{b}$ & $106.61 \pm 1.58^{\mathrm{b}}$ & $108.34 \pm 2.09^{b}$ \\
\hline \multirow{2}{*}{ Lysozyme activity, \% } & A & $37.93 \pm 0.89^{\mathrm{a}}$ & $38.13 \pm 1.00^{\mathrm{a}}$ & $38.69 \pm 0.88^{\mathrm{a}}$ & $38.90 \pm 1.55^{\mathrm{a}}$ & $39.00 \pm 0.72^{\mathrm{a}}$ & $40.90 \pm 1.55^{\mathrm{a}}$ & $41.13 \pm 1.59^{\mathrm{a}}$ & $41.73 \pm 1.59^{\mathrm{a}}$ \\
\hline & B & $38.13 \pm 0.90^{\mathrm{a}}$ & $39.46 \pm 0.91^{\mathrm{a}}$ & $39.70 \pm 0.99^{\mathrm{a}}$ & $40.31 \pm 1.52^{\mathrm{a}}$ & $41.90 \pm 1.43^{\mathrm{a}}$ & $51.35 \pm 1.61^{\mathrm{b}}$ & $52.52 \pm 1.91^{\mathrm{b}}$ & $52.74 \pm 2.11^{\mathrm{b}}$ \\
\hline \multirow{2}{*}{ Bactericidal activity, \% } & A & $38.24 \pm 0.70^{\mathrm{a}}$ & $38.14 \pm 0.76^{\mathrm{a}}$ & $37.93 \pm 1.00^{\mathrm{a}}$ & $37.81 \pm 1.60^{\mathrm{a}}$ & $40.13 \pm 1.87^{\mathrm{a}}$ & $43.20 \pm 2.04^{b}$ & $45.18 \pm 1.41^{\mathrm{b}}$ & $46.13 \pm 1.87^{b}$ \\
\hline & $\mathrm{B}$ & $37.70 \pm 1.08^{\mathrm{a}}$ & $38.12 \pm 0.41^{\mathrm{a}}$ & $38.36 \pm 0.82^{\mathrm{a}}$ & $40.17 \pm 2.01^{\mathrm{a}}$ & $41.10 \pm 1.43^{\mathrm{a}}$ & $48.33 \pm 1.21^{\mathrm{bc}}$ & $57.66 \pm 1.24^{\mathrm{c}}$ & $58.27 \pm 1.58^{\mathrm{c}}$ \\
\hline \multirow{2}{*}{ Phagocytic activity, $\%$} & A & $41.79 \pm 0.67^{\mathrm{a}}$ & $43.10 \pm 0.65^{\mathrm{a}}$ & $44.11 \pm 0.93^{\mathrm{b}}$ & $44.90 \pm 1.58^{b}$ & $46.70 \pm 1.25^{\mathrm{b}}$ & $46.90 \pm 1.26^{\mathrm{b}}$ & $47.16 \pm 1.51^{\mathrm{b}}$ & $47.31 \pm 1.79^{b}$ \\
\hline & $\mathrm{B}$ & $40.56 \pm 1.01^{\mathrm{a}}$ & $43.22 \pm 0.68^{\mathrm{a}}$ & $45.22 \pm 1.21^{\mathrm{b}}$ & $45.37 \pm 1.59^{b}$ & $47.10 \pm 1.45^{\mathrm{b}}$ & $48.70 \pm 1.25^{\mathrm{bc}}$ & $49.90 \pm 1.62^{\mathrm{bc}}$ & $51.27 \pm 2.35^{\mathrm{c}}$ \\
\hline \multirow{2}{*}{ Leukocytes, g/L } & A & $21.35 \pm 0.95^{\mathrm{a}}$ & $20.00 \pm 0.33^{\mathrm{a}}$ & $22.80 \pm 1.02^{\mathrm{a}}$ & $23.58 \pm 0.71^{b}$ & $25.14 \pm 1.44^{b}$ & $20.35 \pm 1.57^{\mathrm{a}}$ & $19.15 \pm 1.59^{\mathrm{a}}$ & $22.70 \pm 1.43^{\mathrm{a}}$ \\
\hline & B & $22.76 \pm 0.72^{\mathrm{a}}$ & $22.21 \pm 0.61^{\mathrm{a}}$ & $22.42 \pm 1.35^{\mathrm{a}}$ & $23.90 \pm 0.60^{b}$ & $25.90 \pm 0.99^{b}$ & $27.62 \pm 1.57^{\mathrm{bc}}$ & $29.01 \pm 0.91^{\mathrm{bc}}$ & $37.90 \pm 1.39^{c}$ \\
\hline \multirow{2}{*}{ Red blood cells, thousand/L } & A & $3.33 \pm 0.43^{\mathrm{a}}$ & $3.18 \pm 0.66^{\mathrm{a}}$ & $3.29 \pm 0.38^{\mathrm{a}}$ & $3.15 \pm 0.50^{\mathrm{a}}$ & $3.19 \pm 0.48^{\mathrm{a}}$ & $3.28 \pm 0.42^{\mathrm{a}}$ & $3.45 \pm 0.39^{\mathrm{a}}$ & $3.56 \pm 0.88^{\mathrm{ab}}$ \\
\hline & $\mathrm{B}$ & $3.28 \pm 0.22^{\mathrm{a}}$ & $3.31 \pm 0.69^{\mathrm{a}}$ & $3.38 \pm 0.32^{\mathrm{a}}$ & $3.24 \pm 0.44^{\mathrm{a}}$ & $3.17 \pm 0.66^{\mathrm{a}}$ & $3.56 \pm 0.40^{\mathrm{ab}}$ & $3.80 \pm 0.55^{\mathrm{b}}$ & $3.90 \pm 0.71^{\mathrm{b}}$ \\
\hline
\end{tabular}

Note: A - control group; B - experiment group; differences between the indicators were taken into account according to the results of the Tukey test $(\mathrm{P}<0.05)$ with $\mathrm{Bonferroni}$ correction.

We also observed a significant increase in the amount of hemoglobin $(108.34 \pm 2.09$ vs $90.96 \pm 1.60 \mathrm{~g} / \mathrm{L})$, which correlates with red blood cell counts in the experimental group compared with the control group. The study also showed a significant increase in lysozyme $(52.74 \pm 2.11$ vs $41.73 \pm 1.59 \%)$ and bactericidal activities of the serum $(58.27 \pm 2.35$ vs $46.13 \pm 1.87 \%$ ). All of these indicators show an increase in poultry resistance to infectious diseases. After all, lysozyme is secreted by phagocytes and is a non-specific effector of the immune system. The indicator of the bactericidal activity of the blood serum of the experimental group increased proportionally along with this observation. The bactericidal activity of blood serum is an integral indicator of the state of the humoral link of the non-specific body resistance, an indicator of the ability to suppress and neutralize microbial agents. The bactericidal activity of blood serum varied significantly over the growing periods, but at the final stage, its activity was more than the results of a study of the research group of chickens, where the disinfectant was used. Evaluation of slaughter qualities and internal organs in 7-weekold broilers showed a higher slaughter yield of the experimental group of chickens by $4 \%$ when using the evisceration technique.

\section{Discussion}

Aerosol disinfection with $0.3 \%$ preparation based on essential oils provided reliable sanitation of the air in the poultry house. Before the start of the study, the total bacterial contamination of the room air in control and experimental groups was $230.2 \pm 15.6$ thousand microbial cells $/ \mathrm{m}^{3}$. After 60 minutes after disinfection, the number of microbial cells decreased to $1.4 \pm 0.4$ thousand microbial cells $/ \mathrm{m}^{3}$. The efficiency was $99 \%$. The $0.3 \%$ disinfectant showed high antibacterial activity against microorganisms indoors in the presence of chickens from the 20th to 35th day and until the end of the study. The latter was confirmed by the lack of growth of microorganisms on nutrient media (meat peptone agar and Saburo agar), which were in the premises after disinfection. Consequently, this concentration is sufficient for effective aerosol disinfection of poultry house premises. Separate disinfectants are used in poultry farming for aerosol disinfection in the presence of birds (Nikolaenko, 2016; Petrova et al., 2016), and some-directly in broiler production (Nikolaenko et al., 2017). However, preparation based on essential oils is a unique formula using disinfectant 
agents and essential oils and can be used effectively as an aerosol against microorganisms in the air.

For aerosol disinfectants, the following requirements are taken into account: not to be toxic, not to irritate mucous membranes, to be invisible, not to smell, not to cause corrosion of metals, not to inflame, to dissolve well in water, not to oxidize, and to saturate air in small quantities. Disinfectants used for aerosol disinfection can be divided into groups: glycols, organic acids, phenolic preparations, chlorine-containing preparations, essential oils, fumes. Thus, the action of ultraviolet light to enhance the bactericidal action of bioaerosol without the addition of disinfectant substances was insufficient for reliable disinfection, but the addition of titanium dioxide $\left(\mathrm{TiO}_{2} \mathrm{P} 25\right)$ and zinc oxide $(\mathrm{ZnO})$ significantly increased the effectiveness of the aerosol (Rodrigues-Silva et al., 2017). These are the essential oils that guarantee high activity of complex preparations against grampositive and gram-negative bacteria, multi-resistant forms of pathogens (MRSA), biofilms, and yeast (Haapakorva et al., 2018). Complexes of metal nanoparticles with essential oils are promising disinfectants and bactericides. The mechanism of their action is based on blocking the amino acid groups of the protein coat and enzyme systems of microorganisms. At the first stage of disinfection, associates of microorganisms with nanoparticles are formed, then the ligand is replaced by an amino acid group of the protein, which leads to complete blocking of metabolic processes in the microorganism and, accordingly, to its death. Silver reacts with the bacterial cell membrane, which is a structure of special proteins peptidoglycans, linked by amino acids to provide mechanical strength and stability. The action of nanosilver is specific not for infection agent, as in antibiotics, but for cell structure. Therefore, the toxic effect on the body of humans and animals of the proposed disinfectant is almost safe.

Currently, a number of multicomponent environmentally friendly disinfectants are used for disinfection in livestock and poultry farming. The most common disinfectants are those based on quarter-ammonium compounds (Ito et al., 2018), and mainly with aldehydes and oxygen-containing oxidation agents. However, the preparations are not effective enough and have a high cost (Dorozhkin et al., 2017). The preparation based on essential oils in contrast to these preparations is quite active and relatively cheap.

The results of our study on the preparation showed the possibility of solving another important problem. Indeed, now antibiotic resistance of bacteria and the prohibition of the use of antibiotics in poultry farming is a reality. To combat intestinal pathogens in this area, formaldehyde is successfully used in appropriate (harmless to the body) concentrations with feed (Khan et al., 2006; Yakhkeshi et al., 2011; Ricke et al., 2019). Indeed, Salmonella, Campylobacter, Escherichia coli and other pathogenic and conditionally pathogenic microorganisms constantly circulate in the air of a poultry house during broiler rearing (Venter et al., 2004; Chinivasagam et al., 2009). The use of our preparation contributes to a significant reduction in the concentration of microorganisms in the air of the poultry house and microbial pressure on the body of poultry. This naturally implies the increase in body weight, its slaughter yield, the increase in physiological parameters and resistance.

The results of our research generally coincide with the data presented in the scientific works of other authors who conducted experiments and analyzed the effect of silver nanoparticles on various pathogens and animal and human bodies. This is especially true of sources that emphasize the need to use drugs based on nanotechnology to combat a large number of antibiotic-resistant microorganisms (Tang \& Zheng, 2018; Shi et al., 2018; Ipe et al, 2020). Our results confirm the data on a wide range of applications of silver nanoparticles and their highly effective antimicrobial properties against gram-positive and gram-negative microorganisms, including pathogens with significant resistance to therapeutic and disinfectant drugs (Durán et al., 2016; Prasher et al., 2018; Coriolano, 2021). Thus, silver nanoparticles are a potential alternative to generally accepted substances used as components of disinfectants.

In addition, the results of studies of the effectiveness of the use of essential oils in the preparation based on essential oils developed by us confirm the data provided in the professional literature that essential oils exhibit a wide range of antibacterial, antifungal, and even antiviral activity, affect drug-resistant microbial strains. They also have antioxidant, antiinflammatory, antimycotoxigenic properties (Tariq et al., 2019; Falleh et al., 2020; Mutlu-Ingok et al., 2020), protistocidal, nematicidal and insecticidal activity (Martynov et al., 2019; Boyko \& Brygadyrenko, 2021; Boyko et al., 2021).

Thus, the data obtained indicate a positive effect of the developed methods and modes of aerosol air treatment with the preparation on the growth and development of broilers.

\section{Conclusions}

The preparation based on essential oils at a concentration of $0.3 \%$ at a dose of $50 \mathrm{~cm}^{3}$ per $1 \mathrm{~m}^{3}$ of air with an exposure of 60 minutes shows high bactericidal activity and provides reliable sanitation of indoor air and is not toxic to chickens when disinfecting in their presence. Treatment with this preparation leads to a significant increase in the amount of hemoglobin, as well as increasing the levels of lysozyme and bactericidal activities.

The author would like to express special thanks to Anatoliy Holovko, Director of the State Scientific Control Institute of Biotechnology and Strains of Microorganisms, and Andrii Mezhenskyi, Director of the State Scientific Research Institute of Laboratory Diagnostics and Veterinary and Sanitary Expertise, for providing assistance in conducting the research.

The authors would like to acknowledge the United States Department of Defense, Defense Threat Reduction Agency (DTRA), and Ukraine Biological Threat Reduction Program (BTRP) for their assistance and financial support in publication of this paper. While DTRA/BTRP did not support the research described in this publication, the Program supported the manuscript development and publication. The contents of this publication are the responsibility of the authors and do not necessarily reflect the views of DTRA or the United States Government.

Authors declare no conflict of interest.

\section{References}

Addie, D. D., Boucraut-Baralon, C., Egberink, H., Frymus, T., Gruffydd-Jones, T., Hartmann, K., Horzinek, M. C., Hosie, M. J., Lloret, A., Lutz, H., Marsilio, F., Pennisi, M. G., Radford, A. D., Thiry, E., Truyen, U., \& Möstl, K. (2015). European advisory board on cat diseases. Disinfectant choices in veterinary practices, shelters and households: ABCD guidelines on safe and effective disinfection for feline environments. Journal of Feline Medicine and Surgery, 17(7), $594-605$.

Alvarez, J., Lopez, G., Muellner, P., de Frutos, C., Ahlstrom, C., Serrano, T., Moreno, M. A., Duran, M., Saez, J. L., Dominguez, L., \& Ugarte-Ruiz, M. (2020). Identifying emerging trends in antimicrobial resistance using Salmonella surveillance data in poultry in Spain. Transboundary and Emerging Diseases, 67(1), 250-262.

Baranowska, M., Chojnowski, W., \& Nowak, H. (2014). Disinfection in diaryplants. Engineering Sciences and Technologies, 4(15), 9-22.

Ben Sassi, N., Averós, X., \& Estevez, I. (2016). Technology and poultry welfare. Animals, 6(10), 62.

Biesek, J., Kuźniacka, J., Banaszak, M., Kaczmarek, S., Adamski, M., Rutkowski, A., Zmudzińska, A., Perz, K., \& Hejdysz, M. (2020). Growth performance and carcass quality in broiler chickens fed on legume seeds and rapeseed meal. Animals, 10(5), 846 .

Borges, C. A., Tarlton, N. J., \& Riley, L. W. (2019). Escherichia coli from commercial broiler and backyard chickens share sequence types, antimicrobial resistance profiles, and resistance genes with human extraintestinal pathogenic Escherichia coli. Foodborne Pathogens and Disease, 16(12), 813-822.

Boyko, O., \& Brygadyrenko, V. (2021). Nematicidal activity of essential oils of medicinal plants. Folia Oecologica, 48(1), 42-48.

Boyko, O., Shendryk, L., Shaban, O., \& Brygadyrenko, V. (2021). Influence of essential oils on sporulation of Eimeria magna oocysts. Annals of Parasitology, 67(1), 11-17.

Buckmaster, C. (2012). Shifting the culture of lab animal care. Lab Animal, 41(7), 205.

Carvalho, M. R. A., dos Santos da Silva, M. A., de Sousa Brito, C. A. R., Campelo, V., Kuga, M. C., Tonetto, M. R., De Jesus Tavarez, R. R., Bandéca, M. C., \& Pinzan-Vercelino, C. R. M. (2015). Comparison of antimicrobial activity between chemical disinfectants on contaminated orthodontic pliers. The Journal of Contemporary Dental Practice, 16(8), 619-623.

Chaidez, C., Lopez, J., \& Castro-Del Campo, N. (2007). Quaternary ammonium compounds: An alternativedisinfection method for fresh produce wash water. Journal of Water and Health, 5(2), 329-333.

Chinivasagam, H. N., Tran, T., Maddock, L., Gale, A., \& Blackall, P. J. (2009). Mechanically ventilated broiler sheds: A possible source of aerosolized Salmo- 
nella, Campylobacter, and Escherichia coli. Applied and Environmental Microbiology, 75(23), 7417-7425.

Coriolano, D., de Souza, J., Bueno, E., Medeiros, S., Cavalcanti, I. D., \& Cavalcanti, I. M. (2021). Antibacterial and antibiofilm potential of silver nanoparticles against antibiotic-sensitive and multidrug-resistant Pseudomonas aeruginosa strains. Brazilian Journal of Microbiology, 52(1), 267-278.

Das, S., Gazdag, Z., Szente, L., Meggyes, M., Horváth, G., Lemli, B., Kunsági-Máté, S., Kuzma, M., \& Kőszegi, T. (2019). Antioxidant and antimicrobial properties of randomly methylated $\beta$ cyclodextrin - captured essential oils. Food Chemistry, 278, 305-313.

Diadychkyna, L. F. (2011). Veterinarno-profilakticheskiye meropriyatiya v inkubatorii [Veterinary preventive measures in the hatchery]. Poultry Farm, 4, 32-36 (in Russian).

Diaz, D., Church, J., Young, M., Kim, K. T., Park, J., Hwang, Y. B., Swadeshmukul, S., \& Lee, W. H. (2019). Silica-quaternary ammonium "Fixed-Quat" nanofilm coated fiberglass mesh for water disinfection and harmful algal blooms control. Journal of Environmental Sciences, 82, 213-224.

Ding, S., Deng, Y., Bond, T., Fang, C., Cao, Z., \& Chu, W. (2019). Disinfection byproduct formation during drinking water treatment and distribution: A review of unintended effects of engineering agents and materials. Water Research, 160, 313-329.

Dorozhkin, V. I., Prokopenko, A. A., Morozov, V. J., \& Dronfort, M. I. (2017). Preparaty dlja dezinfekcii obektov veterinamogo nadzora [Preparations for disinfection of objects of veterinary supervision]. Pticevodstvo, 5, 50-53 (in Russian).

Durán, N., Durán, M., de Jesus, M., Seabra, A., Fávaro, W., \& Nakazato, G. (2016). Silver nanoparticles: A new view on mechanistic aspects on antimicrobial activity. Nanomedicine, 12(3), 789-799.

Falleh, H., Jemaa, M., Saada, M., \& Ksouri, R. (2020). Essential oils: A promising eco-friendly food preservative. Food Chemistry, 330, 127268

Feng, Q. L., Wu, J., Chen, G. Q., Cui, F. Z., Kim, T. N., \& Kim, J. O. (2000). A mechanistic study of the antibacterial effect of silver ions on Escherichia coli and Staphylococcus aureus. Joumal of Biomedical Materials Research, 52(4), 662-668.

Fewtrell, L., Majuru, B., \& Hunter, P. R. (2017). A re-assessment of the safety of silver in household water treatment: Rapid systematic review of mammalian in vivo genotoxicity studies. Environmental Health, 16, 66.

Fyhrquist, P., Virjamo, V., Hiltunen, E., \& Julkunen-Tiitto, R. (2017). Epidihydropinidine, the main piperidine alkaloid compound of Norway spruce (Picea abies) shows promising antibacterial and anti-Candida activity. Fitoterapia, 117, 138-146.

Haapakorva, E., Holmbom, T., \& von Wright, A. (2018). Novel aqueous oil-in-water emulsions containing extracts of natural coniferous resins are strongly antimicrobial against enterobacteria, staphylococci and yeasts, as well as on bacteria biofilms. Journal of Applied Microbiology, 124(1), 136-143.

Hatchett, D. W., \& White, H. S. (1996). Electrochemistry of sulfur ad layers on lowindex faces of silver. The Journal of Physical Chemistry, 100(23), 9854-9859.

Ibragimov, A. A. (2007). Patomorfologija i diagnostika boleznej ptic: Atlas [Pathomorphology and diagnosis of avian diseases: Atlas]. Kolos, Moskov (in Russian).

Ipe, D., Kumar, S., Love, R., \& Hamlet, S. (2020). Silver nanoparticles at biocompatible dosage synergistically increases bacterial susceptibility to antibiotics. Frontiers in Microbiology, 11, 1074.

Ito, M., Alam, M. S., Suzuki, M., Takahashi, S., Komura, M., Sangsriratakul, N., Shoham, D., \& Takehara, K. (2018). Virucidal activity of a quaternary ammonium compound associated with calcium hydroxide on avian influenza virus, Newcastle disease virus and infectious bursal disease virus. The Journal of Veterinary Medical Science, 80(4), 574-577.

Jiang, L., Li, M., Tang, J., Zhao, X., Zhang, J., Zhu, H., Yu, X., Li, Y., Feng, T., \& Zhang, X. (2018). Effect of different disinfectants on bacterial aerosol diversity in poultry houses. Frontiers in Microbiology, 9, 2113.

Just, N., Kirychuk, S., Gilbert, Y., Letourneau, V., Veillette, M., Singh, B., \& Duchaine, C. (2011). Bacterial diversity characterization of bioaerosols from cagehoused and floor-housed poultry operations. Environmental Research, 111(4), 492-498.

Khan, A., Hussain, S. M., \& Khan, M. Z. (2006). Effects of formalin feeding or administering into the crops of white leghom cockerels on hematological and biochemical parameters. Poultry Science, 85(9), 1513-1519.

Kim, H. R., Hwang, G. W., Naganuma, A., \& Chung, K. H. (2016). Adverse health effects of humidifier disinfectants in Korea: Lung toxicity of polyhexamethylene guanidine phosphate. The Journal of Toxicological Sciences, 41(6), 711-717.

Kim, H. S., \& Park, H. D. (2013). Ginger extract inhibits biofilm formation by Pseudomonas aeruginosa PA14. PLoS One, 8(9), e76106.

Kim, J. S., Kuk, E., Yu, K. N., Kim, J. H., Park, S. J., Lee, H. J., Kim, S. H., Park, Y. K., Park, Y. H., Hwang, C. Y., Kim, Y. K., Lee, Y. S., Jeong, D. H., \& Cho, M. H. (2007). Antimicrobial effects of silver nanoparticles. Nanomedicine: Nanotechnology, Biology, and Medicine, 3(1), 95-101.

Köhler, A. T., Rodloff, A. C., Labahn, M., Reinhardt, M., Truyen, U., \& Speck, S. (2019). Evaluation of disinfectant efficacy against multidrug-resistant bacteria: A comprehensive analysis of different methods. American Journal of Infection Control, 47(10), 1181-1187.
Kotsiumbas, I. Y., Malik, O. G., \& Paterega, I. P. (2006). Doklinicheskiye issledovaniya veterinarnykh preparatov [Preclinical studies of veterinary drugs]. Triada Plus, Lviv (in Ukrainian).

Kovalenko, V. L., Jakubchak, O. N., Jashhenko, M. F., Tjutjun, A. I., \& Adamenko, L. V. (2011). Sanitarno-mikrobiologicheskij kontrol' vozduha ob'ektov veterinamosanitarnogo nadzora i kontrolja [Sanitary and microbiological control of objects of veterinary and sanitary supervision and control]. Guidelines, Kiev (in Ukrainian)

Kovalenko, V. L., Kovalenko, P. L., Ponomarenko, G. V., Kukhtyn, M. D., \& Garkavenko, V. M. (2018). Changes in lipid composition of Escherichia coli and Staphylococcus areus cells under the influence of disinfectants Barez, Biochlor and Geocide. Ukrainian Journal of Ecology, 8(1), 547-550.

Lagha, R., Abdallah, F. B., AL-Sarhan, B. O., \& Al-Sodany, Y. (2019). Antibacterial and biofilm inhibitory activity of medicinal plant essential oils against Escherichia coli isolated from UTI patients. Molecules, 24(6), 1161

Liau, S. Y., Read, D. C., Pugh, W. J., Furr, W. J., \& Russell, A. D. (1997). Interaction of silver nitrate with readily identifiable groups: Relationship to the antibacterial action of silver ions. Letters in Applied Microbiology, 25, 279-283.

Lopes, L. Q., Santos, C. G., de Almeida Vaucher, R., Gende, L., Raffin, R. P., \& Santos, R. C. (2016). Evaluation of antimicrobial activity of glycerol monolaurate nanocapsules against American foulbrood disease agent and toxicity on bees. Microbial Pathogenesis, 97, 1883-1888.

Maertens, H., De Reu, K., Van Weyenberg, S., Van Coillie, E., Meyer, E., Van Meirhaeghe, H., Van Immerseel, F., Vandenbroucke, V., Vanrobaeys, M., \& Dewulf, J. (2018). Evaluation of the hygienogram scores and related data obtained after cleaning and disinfection of poultry houses in flanders during the period 2007 to 2014. Poultry Science, 97(2), 620-627.

Man, A., Santacroce, L., Jacob, R., Mare, A., \& Man, L. (2019). Antimicrobial activity of six essential oils against a group of human pathogens. Pathogens, $8(1), 15$

Martynov, V. O., Titov, O. G., Kolombar, T. M., \& Brygadyrenko, V. V. (2019). Influence of essential oils of plants on themigration activity of Tribolium confusum (Coleoptera, Tenebrionidae). Biosystems Diversity, 27(2), 177-185.

Matsumura, Y., Yoshikata, K., Kunisaki, S., \& Tsuchido, T. (2003). Mode of bacterial action of silver zeolite and its comparison with that of silver nitrate. Applied and Environmental Microbiology, 69(7), 4278 -4281.

McDonnell, G., \& Russell, A. D. (1999). Antiseptics and disinfectants: Activity, action and resistance. Clinical Microbiology Reviews, 12, 147-179.

Morones, J. R., Elechiguerra, J. L., Camacho, A., Holt, K., Kouri, J. B., Ramirez J. T., \& Yacaman, M. J. (2005). The bactericidal effect of silver nanoparticles. Nanotechnology, 16(10), 2346-2353.

Mutlu-Ingok, A., Devecioglu, D., Dikmetas, D., Karbancioglu-Guler, F., \& Capanoglu, E. (2020). Antibacterial, antifungal, antimycotoxigenic, and antioxidan activities of essential oils: An updated review. Molecules, 25(20), 4711

National Research Council (2011). Guide for the care and use of laboratory animals. The National Academies Press, Washington.

Nikolaenko, V. P. (2016). Profilaktika i lechenie infekcionnyh boleznej v pticevodstve [Prevention and treatment of infectious diseases in poultry farming]. Pticevodstvo, 9, 53-56 (in Russian).

Nikolaenko, V. P Shestakov, I. N, Kononov, A. N, Ozheredova, N. A, Mihajlova A. V., \& Shhedrov, I. N. (2017). Preparat Nikosan dlia aerozol'nogo primenenija pri vyrashhivanii brojlerov [Nikosan preparation for aerosol use in broiler rearing]. Veterinarija, 10, 43-45 (in Russian).

Olaimat, A. N., Al-Holy, M. A., Ghoush, M. H. A., Al-Nabulsi, A. A., Tareq, M. O., \& Holley, R. A. (2019). Inhibitory effects of cinnamon and thyme essential oils against Salmonella spp. in hummus (chickpea dip). Journal of Food Processing and Preservation, 43(5), e13925.

Paliy, A. P., Ishchenko, K. V., Marchenko, M. V., Paliy, A. P., \& Dubin, R. A. (2018). Effectiveness of aldehyde disinfectant against the causative agents of tuberculosis in domestic animals and birds. Ukrainian Journal of Ecology, 8(1) 845-850.

Park, H. J., Kim, J. Y., Kim, J., Lee, J. H., Hahn, J. H., Gu, M. B., \& Yoon, J. (2009) Silver-ion-mediated reactive oxygen species generation affecting bactericidal activity. Water Research, 43, 1027-1032.

Petkov, G., Baikov, B. D., \& Russak, G. (1987). Possibilities for decontaminating the air in commercial poultry breeding. Veterinarno-Meditsinski Nauki, 24(3), 67-72.

Petrova, O. G., Barashkin, M. I., \& Mil'shtejn, I. M. (2016). Vetargent-sovremennoe dezinficinujushhee sredstvo dlia primenenija v pticevodstve [Vetargent is a modem disinfectant for use in poultry farming]. Veterinarija, 11, 47-48 (in Russian).

Ponomarenko, G. V., Kovalenko, V. L., Ponomarenko, O. V., \& Balackiy, Y. O. (2017). Effects of microbicide based on lactic acid and metal nanoparticles on laboratory animals. Ukrainian Journal of Ecology, 7(4), 482-485.

Prasher, P., Singh, M., \& Mudila, H. (2018). Silver nanoparticles as antimicrobial therapeutics: Current perspectives and future challenges. 3 Biotech, 8(10), 411

Rawson, T., Dawkins, M. S., \& Bonsall, M. B. (2019). A mathematical model of Cam pylobacter dynamics within a broiler flock. Frontiers in Microbiology, 10, 1940.

Richards, M. J., Hsia, C. Y., Singh, R. R., Haider, H., Kumpf, J., Kawate, T., \& Daniel, S. (2016). Membrane protein mobility and orientation preserved in sup- 
ported bilayers created directly from cell plasma membrane blebs. Langmuir, 32(12), 2963-2974

Ricke, S. C., Richardson, K., \& Dittoe, D. K. (2019). Formaldehydes in feed and their potential interaction with the poultry gastrointestinal tract microbial community - a review. Frontiers in Veterinary Science, 6, 188.

Rodionova, K., Paliy, A., \& Khimych, M. (2021). Veterinary and sanitary assessment and disinfection of refrigerator chambers of meat processing enterprises. Potravinarstvo Slovak Journal of Food Sciences, 15, 616-626.

Rodrigues-Silva, C., Miranda, S. M., Lopes, F. V. S., Silva, M., Dezotti, M., Silva, A. M. T., Faria, J. L., Boaventura, R. A. R., Vilar, V. J. P., \& Pinto, E. (2017) Bacteria and fungi inactivation by photocatalysis under UVA irradiation: Liquid and gas phase. Environmental Science and Pollution Research, 24(7), 6372-6381.

Saklou, N. T., Burgess, B. A., Van Metre, D. C., Hornig, K. J., Morley, P. S., \& Byers, S. R. (2016). Comparison of disinfectant efficacy when using highvolume directed mist application of accelerated hydrogen peroxide and peroxymonosulfate disinfectants in a large animal hospital. Equine Veterinary Journal, 48(4), 485-489.

Shi, T., Sun, X., \& He, Q.-Y. (2018). Cytotoxicity of silver nanoparticles against bacteria and tumor cells. Current Protein and Peptide Science, 19(6), 525-536.

Soliman, S. S. M., Alsaadi, A. I., Youssef, E. G., Khitrov, G., Noreddin, A. M., Husseiny, M. I., \& Ibrahim, A. S. (2017). Calli essential oils synergize with Lawsone against multidrug resistant pathogens. Molecules, 22(12), 2223.

Sondi, I., \& Salopek-Sondi, B. (2004). Silver nanoparticles as antimicrobial agent: A case study on E. coli as a model for Gram-negative bacteria. Journal of Colloid and Interface Science, 275(1), 177-182.

Souza, A. L., Ceridório, L. F., Paula, G. F., Mattoso, L. H., \& Oliveira Jr., O. N (2015). Understanding the biocide action of poly(hexamethylene biguanide) using Langmuir monolayers of dipalmitoyl phosphatidylglycerol. Colloids and surfaces, B, Biointerfaces, 132, 117-121.

Suchomel, M., Lenhardt, A., Kampf, G., \& Grisold, A. (2019). Enterococcus hirae Enterococcus faecium and Enterococcus faecalis show different sensitivities to typical biocidal agents used for disinfection. The Joumal of Hospital Infection, 103(4), 435-440

Taiwo, M. O., \& Adebayo, O. S. (2017). Plant essential oil: An alternative to emerging multidrug resistant pathogens. Journal of Microbiology and Experimentation, 5(5), 163.

Tang, S., \& Zheng, J. (2018). Antibacterial activity of silver nanoparticles: Structural effects. Advanced Healthcare Materials, 7(13), e1701503.

Tariq, S., Wani, S., Rasool, W., Shafi, K., Bhat, M. A., Prabhakar, A., Shalla, A. H., \& Rather, M. A. (2019). A comprehensive review of the antibacterial, antifungal and antiviral potential of essential oils and their chemical constituents against drug-resistant microbial pathogens. Microbial Pathogenesis, 134, 103580

Vandepitte, J., Verhaegen, J., Engbaek, K., Rohner, P., Piot, P., \& Heuck, C. C. (2003). Basic laboratory procedures in clinical bacteriology. 2nd ed. World Health Organization, Geneva

Vasireddy, L., Bingle, L. E. H., \& Davies, M. S. (2018). Antimicrobial activity of essential oils against multidrug-resistant clinical isolates of the Burkholderia cepacia complex. PLoS One, 13, e0201835.

Venter, P., Lues, J. F. R., \& Theron, H. (2004). Quantification of bioaerosols in automated chicken egg production plants. Poultry Science, 83(7), 1226-1231.

Wojnicz, D., Kucharska, A.Z., Sokól-Letowska, A., Kicia, M., \& Tichaczek-Goska, D. (2012). Medicinal plants extracts affect virulence factors expression and biofilm formation by the uropathogenic Escherichia coli. Urological Research, 40(6), 683-697.

Yakhkeshi, S., Rahimi, S., \& Naseri, K. G. (2011). The effects of comparison of herbal extracts, antibiotic, probiotic and organic acid on serum lipids, immune response, GIT microbial population, intestinal morphology and performance of broilers. Journal of Medicinal Plants, 10(37), 80-95.

Zazharskyi, V. V., Davydenko, P. O., Kulishenko, O. M., Borovik, I. V., Zazharska, N. M., \& Brygadyrenko, V. V. (2020). Antibacterial and fungicidal activities of ethanol extracts of 38 species of plants. Biosystems Diversity, 28(3), 281-289. 